\section{A note on the inheritance of the hereditary persistence of fetal haemoglobin and the $\delta$-chain variant $\mathrm{Hb}-\mathrm{A}_{2}^{\prime}$}

The most common form of the condition known as the hereditary persistence of fetal haemoglobin (HPFH) is characterized by a continued synthesis of $\mathrm{Hb}-\mathrm{F}$ and an absence of $\beta$ - and $\delta$-chain synthesis by the chromosome carrying the HPFH determinant. This conclusion is based on observations made in homozygotes who produce $\mathrm{Hb}-\mathrm{F}$ only; in subjects heterozygous for the $\beta$-chain variant $\mathrm{Hb}-\mathrm{S}$ and for the HPFH condition who produce $\mathrm{Hb}-\mathrm{S}, \mathrm{Hb}-\mathrm{F}$, a decreased amount of $\mathrm{Hb}-\mathrm{A}_{2}$ and no $\mathrm{Hb}-\mathrm{A}$; and in one subject who is heterozygous for the HPFH condition and the $\delta$-chain variant $\mathrm{Hb}-\mathrm{A}_{2}{ }^{\prime}$, producing $\mathrm{Hb}-\mathrm{F}, \mathrm{Hb}-\mathrm{A}, \mathrm{Hb}-\mathrm{A}_{2}{ }^{\prime}$, and no $\mathrm{Hb}-\mathrm{A}_{2}$ (Huisman et al, 1971; Huisman, 1972). Recently we were able to study a large family in which the HPFH anomaly and the $\mathrm{Hb}-\mathrm{A}_{2}{ }^{\prime}$ variant occurred separately and in combination with each other, thus allowing a further evaluation of the inheritance of these two conditions.

The family consisted of the parents, three sons, and five daughters. Blood samples were analysed by routine haematological procedures using a Coulter Counter Model S. Haemoglobin in red cell haemolysates was analysed by starch gel electrophoresis at pH 9.0 (Efremov et al, 1969), by an alkali denaturation procedure to determine the percent $\mathrm{Hb}-\mathrm{F}$ ( $\% \mathrm{~F}_{\mathrm{AD}}$ (Betke et al, 1959)), and by DEAE-Sephadex chromatography to quantitate the levels of $\mathrm{Hb}-\mathrm{A}_{2}$ and $\mathrm{Hb}-\mathrm{A}_{2}{ }^{\prime}$ (Huisman and Dozy, 1965; Dozy et al, 1968). The data are given in the Table. The father appears to have a HPFH heterozygosity and the mother a heterozygosity for the $\delta$-chain variant $\mathrm{Hb}-\mathrm{A}_{2}{ }^{\prime}$. Three of their children are normal, one has the $\mathrm{Hb}-\mathrm{A}_{2}{ }^{\prime}$ heterozygosity, two have the HPFH heterozygosity, and two have the HPFH heterozygosity as well as the $\mathbf{H b}-\mathbf{A}_{2}{ }^{\prime}$ heterozygosity. The level of $\mathbf{H b}-\mathbf{A}_{2}$ in

Received 15 November 1974.
TABLE

HAEMATOLOGICAL AND HAEMOGLOBIN COMPOSITION DATA ON FAMILY MEMBERS

\begin{tabular}{l|c|c|c|c|c|c|c}
\hline & Age & $\begin{array}{c}\mathrm{Hb} \\
(\mathrm{g} / \mathrm{dl})\end{array}$ & $\mathrm{PCV}$ & $\begin{array}{r}\mathrm{RBC} \\
\left(\times 10^{12} / 1\right)\end{array}$ & $\begin{array}{c}\mathrm{F}_{\mathrm{AD}} \\
(\%)\end{array}$ & $\begin{array}{c}\mathrm{A}_{2} \\
(\%)\end{array}$ & $\begin{array}{c}\mathrm{A}_{2}^{\prime} \\
(\%)\end{array}$ \\
\hline Father & 58 & 12.7 & 38 & 4.31 & 21.5 & 2.2 & 0 \\
Mother & 52 & 11.9 & 36 & 4.03 & 1.0 & 1.3 & 1.1 \\
\hline Son & 27 & 13.5 & 40 & 4.79 & 0.6 & 2.7 & 0 \\
Daughter & 25 & 12.2 & 37 & 4.05 & 1.1 & 2.4 & 0 \\
Daughter & 23 & 13.7 & 41 & 5.00 & 21.7 & 0 & 2.0 \\
Daughter & 20 & 12.1 & 36 & 4.27 & 0.6 & 1.7 & 1.3 \\
Daughter & 19 & 11.9 & 36 & 4.68 & 21.0 & 1.7 & 0 \\
Son & 18 & 14.1 & 42 & 4.89 & 23.4 & 1.6 & 0 \\
Son & 15 & 12.9 & 39 & 5.05 & 21.7 & 0 & 1.8 \\
Daughter & 12 & 11.9 & 35 & 4.41 & 0.7 & 2.7 & 0 \\
\hline
\end{tabular}

the three normal family members $(2.4,2.7$, and $2.7 \%$ ) is comparable to that of the sum of $\mathrm{Hb}-\mathrm{A}_{2}$ and $\mathrm{Hb}-\mathrm{A}_{2}{ }^{\prime}$ in the two $\mathrm{Hb}-\mathrm{A}_{2}{ }^{\prime}$ heterozygotes $(2.4$ and $3.0 \%$ ) and is distinctly more than that of $\mathrm{Hb}-\mathrm{A}_{2}$ in the HPFH heterozygotes $(1.6,1.7$, and $2.2 \%$ ) and of $\mathrm{Hb}-\mathrm{A}_{2}{ }^{\prime}$ in the two persons with the $\mathrm{Hb}-\mathrm{A}_{2}{ }^{\prime}$ HPFH condition (1.8 and $2.0 \%$ ) who do not produce any $\mathrm{Hb}-\mathrm{A}_{2}$.

The complete absence of $\mathrm{Hb}-\mathrm{A}_{2}$ in the two individuals with the $\mathrm{Hb}-\mathrm{A}_{2}{ }^{\prime}-\mathrm{HPFH}$ combination confirms previously published, rather incomplete, data (Huisman et al, 1971) and offers additional evidence that $\delta$-chain production is absent on the chromosome carrying this HPFH determinant.

These studies were supported in part by US Public Health Service Research Grants HL-01568 and HL15158.

T. H. J. HuISMan,* MARSha E. Gravely,* and ROBERT SOX†

* Laboratory of Protein Chemistry, and Comprehensive Sickle Cell Center, Medical College of Georgia, Augusta, Georgia 30902 , USA.

† South Carolina State Board of Health, Columbia, South 62 


\section{REFERENCES}

Betke, K., Marti, H. R., and Schlicht, I. (1959). Estimation of small percentages of foetal haemoglobin. Nature, 184, 1877-1878.

Dozy, A. M., Kleihauer, E. F., and Huisman, T. H. J. (1968). Studies on the heterogeneity of hemoglobin. XIII. Chromatography of various human and animal hemoglobin types on DEAESephadex. Fournal of Chromatography, 32, 723-727.

Efremov, G. D., Huisman, T. H. J., Smith, L. L., Wilson, J. B., Kitchens, J. L., Wrightstone, R. N., and Adams, H. R. (1969). Hemoglobin Richmond, a human hemoglobin which forms asymmetric hybrids with other hemoglobins. Fournal of Biological Chemistry, 244, 6105-6116.
Huisman, T. H. J. (1972). Normal and abnormal human hemoglobins. Advances in Clinical Chemistry, 15, 149-253.

Huisman, T. H. J. and Dozy, A. M. (1965). Studies on the heterogeneity of hemoglobin. IX. The use of tris-(hydroxymethyl)aminoethane- $\mathrm{HCl}$ buffers in the anion-exchange chromatography of hemoglobins. Fournal of Chromatography, 18, 160-169.

Huisman, T. H. J., Schroeder, W. A., Charache, S., Bethlenfalvay, N. C., Bouver, N., Shelton, J. R., Shelton, J. B., and Apell, G. (1971). Hereditary persistence of fetal hemoglobin. Heterogeneity of fetal hemoglobin in homozygotes and in conjunction with $\beta$-thalassemia. New England fournal of Medicine, 285, 711716.

\section{Announcements}

Data on cytogenetic registers

The International Advisory Committee on Cytogenetic Registers to the Standing Committee on Standardization in Human Cytogenetics was charged with the responsibility of compiling, updating, and publishing a list of cytogenetic registers, together with summaries of aims, objectives, and key elements. The committee has developed a form for the collection of such data and invites individuals who operate Cytogenetic Registers (either in isolation or as part of a larger register system) to write for these data forms as soon as possible to Dr James R. Miller, Department of Medical Genetics, The University of British Columbia, Vancouver, B.C., V6T 1W5, Canada.

\section{Eighth Stadler Genetics Symposium}

The eighth Stadler Genetics Symposium will be held in the University of Missouri, 9-10 April 1976. Information and detailed programmes can be obtained by writing to: Conferences and Short Courses, University of Missouri, 347 Hearnes Building, Columbia, MO 65201, U.S.A.

\section{Teratology Society: 1976 Annual Meeting}

The Teratology Society will hold its Sixteenth Annual Meeting 20-23 June 1976 at Highlands Inn, Carmel, California, U.S.A.

Further information can be obtained by writing to $\mathrm{Dr}$ Lucille S. Hurley, Department of Nutrition, University California, Davis, California 95616, U.S.A. 